\title{
Adolescents' Perception about Photoprotection Measures for the Prevention of Skin Cancer
}

\author{
Carla Sola Deponte1 1 , Eloísa Müller Antigo² ${ }^{\circledR}$, Isadora Silveira Rossetto 2 (ㄷ, \\ Caio Sola Deponte ${ }^{3}$ (D), Marcelo Valentim Mansano 2 (D), Sandra Maria Braz Sola Deponte ${ }^{(0)}$, \\ Ieda Francischetti 1
}

\author{
${ }^{1}$ Faculdade de Medicina de Marília, FAMEMA, Marilia, Brazil \\ ${ }^{2}$ Faculdade de Medicina de Dracena, UNIFADRA, Dracena, Brazil \\ ${ }^{3}$ Hospital Estadual Américo Brasiliense, USP, Américo Brasiliense, Brazil \\ Email: ca_deponte@yahoo.com.br
}

How to cite this paper: Deponte, C. S., Antigo, E. M., Rossetto, I. S., Deponte, C. S., Mansano, M. V., Deponte, S. M. B. S., \& Francischetti, I. (2021). Adolescents' Perception about Photoprotection Measures for the Prevention of Skin Cancer. Creative Education, 12, 2972-2986.

https://doi.org/10.4236/ce.2021.1212223

Received: November 9, 2021

Accepted: December 28, 2021

Published: December 31, 2021

Copyright $\odot 2021$ by author(s) and Scientific Research Publishing Inc. This work is licensed under the Creative Commons Attribution International License (CC BY 4.0).

http://creativecommons.org/licenses/by/4.0/

\begin{abstract}
Introduction: The prevention of skin cancer must be carried out from childhood, requiring educational actions to promote healthy habits. Goals: To analyze influencing elements in photoprotective attitudes and to develop photoeducational material for children and adolescents. Method: This was a semiexperimental, qualitative study of educational intervention on photoprotection, applied to 32 students from the eighth grade of primary school. Sociodemographic and phenotypic data related to risk for skin cancer and factors that influence the practice of preventive attitudes was analyzed. Results: The analysis showed the need for a differentiated approach to adolescents, including regarding issues such as acne, refractive errors in vision, vitamin $\mathrm{D}$ and tan culture. Conclusion: The results gave rise to an educational material that synthesizes photoprotection measures and encourages the practice of photoprotective attitudes.
\end{abstract}

\section{Keywords}

Educational and Dissemination Materials, Health Education, School Health Services, Prevention of Diseases, Skin Neoplasms, Continuing Education

\section{Introduction}

\subsection{Skin Cancer: General Characteristics and Epidemiology}

Among the most common malignant skin neoplasms, there is the non-melanoma type, which includes basal cell carcinoma and squamous cell carcinoma. Basal cell carcinoma, originating from cells in the basal layer of the epidermis, has its 
aggressiveness conferred on its power to invade and destroy notable sites (Sampaio \& Rivitti, 2018, Chinem \& Miot, 2011; Lomas et al., 2012). On the other hand, squamous cell carcinoma originates from cells in the spinous layer of the dermis, with a more invasive and metastatic character (Sampaio \& Rivitti, 2018). Both neoplasms mentioned above occur more frequently after 40 years of age, in white-skinned individuals, whose ability to tan is small, being classified as a low skin phototype (Chen et al., 2013; Fitzpatrick, 1988).

The skin neoplasm called melanoma differs in several aspects from the nonmelanoma epithelial neoplasm: it has a high degree of malignancy and originates from melanocytes, present in the basal layer of the epidermis, and from nevus cells (Sampaio \& Rivitti, 2018; Weyers, 2012). One of its subtypes, acral lentiginous melanoma, occurs mainly in black skin, occurring in less pigmented extremities, such as the palmoplantar regions (Weyers, 2012).

The genesis of skin neoplasms is related to exposure to ultraviolet rays (UVR) present in sunlight, since childhood, being acute and intermittent or chronic, and also to exposure to artificial ultraviolet radiation, such as in tanning beds (Ribeiro et al., 2016; Nilsen et al., 2016).

In addition to being one of the most prevalent cancers worldwide, including Brazil, it is aggravated by its delayed diagnosis and difficult treatment, generating high costs to Public Health and detriment to the quality of life due to the increase in morbidity and mortality of the population (Bataille, 2013; Pan American Health Organization, 2018).

Thus, photoprotection measures must be adopted, as the best way to prevent skin cancer, to control the incidence of new cases, to seek early diagnosis, to carry out curative treatment and, finally, to avoid morbidity and death (Global Cancer Observatory, 2018; Schalka et al., 2014).

\subsection{Photoprotection and Photoeducation in Early Childhood and Adolescence}

Photoprotective measures include photoeducation, topical (sunscreen), oral and mechanical (clothing, accessories, shade) protection (Martinez et al., 2006). Children and adolescents are more receptive to the inclusion of new habits and can influence other family members, therefore, they also encourage the adoption of photoprotective habits more effectively (Martinez et al., 2006; Szklo et al., 2007; Brasil-Ministério da Saúde, 2010; INCA, 2009; Lower et al., 1998; Buller et al., 2011; Lin et al., 2011).

In a study on education for adolescents, by Alonso, published in 2020, the search for the development of safe attitudes is emphasized, investing in three skills: perception of risk, knowledge and positive attitudes, and understanding of the significant effects on behavior. The influence of the social microenvironment in which these young individuals are inserted helps to formulate interventions that can potentially involve the school environment, teachers, parents, friends and relatives, as a way to fully address the problem.

The Brazilian Photoprotection Consensus of the Brazilian Society of Derma- 
tology (Sociedade Brasileira de Dermatologia-SBD), also recommends interaction between medical students and children/ adolescents, a more youthful and assertive language, and space for clarification of doubts and private conversations (Martinez et al., 2006).

Few studies on the knowledge and habits of photoprotection in Brazil are available in the literature. Among these, a study carried out in the city of Porto Alegre, among adolescents, shows that, although well-informed, adolescents do not adopt photoprotection habits. Among boys, sun exposure is more frequent during the practice of physical activity, whereas in girls, sun exposure is more frequent during walks and swimming in the pool. Furthermore, the study shows that the main source of information are campaigns published in the media, and emphasizes the need for a discussion using different resources to incorporate these measures among children and adolescents (Rodriguez-Zamorano et al., 2018; da Rocha et al., 2018).

\subsection{Innovative Strategies and Building New Habits}

In the process of "health literacy", a term used by Simmon et al. and Rodriguez, in 2018, who defend the use of active methods and the encouragement of student proactivity in the acquisition of knowledge in an integral and interdisciplinary way, meaningful learning is sought, which is one of the pillars for changing habits (Reynolds et al., 1996; Bastuji-Garin et al., 1999).

Active methods such as problem-based learning and problematization methodology encourage students to actively seek solutions, developing creativity and autonomy (Simmons et al., 2017; Souza et al., 2018; Thomson, 2006). This is a strategy that generates motivation, which facilitates the resolution of these problems, and shows the ability of students to become responsible for their own successes and changes (da Rocha et al., 2018). The best way to invest in behavior is with repetitive training sessions, not short, intensive, or one-off experiences (Reynolds et al., 1996).

The effectiveness of educational measures is also dependent on the pedagogical capacity of the proposals developed in health education and its potential for raising awareness (Rodriguez-Zamorano et al., 2018). The student's motivation arises after being aware of his potential for contribution and resolution, and this engagement is necessary to change behavior and habits (Bastuji-Garin et al., 1999).

As young individuals have more ability to acquire new knowledge, develop and maintain new habits, the strong social representation of teachers as an example in society and their skills to contribute to this process is used (Eppinger et al., 2013; Guy et al., 2016).

Considering the effects of cumulative photoexposure, the potential of active health education (Lima, 2017), the awareness of young individuals and the social representation of educators as mediators, this study aims to develop an educational intervention aimed at promoting health and preventing cancer for primary school students through public school teachers previously oriented on the subject and qualified to use an active teaching-learning method. 
Active and dialogical intervention must be able to engage teachers and students, enable joint construction of significant knowledge and lead to changes in habits and new attitudes aimed at preventing skin cancer (Eppinger et al., 2013; Guy et al., 2016; Jha et al., 2017).

\subsection{Goals}

This study seeks to understand the perception of adolescent primary school students about the influential factors in the practice of photoprotective attitudes, after an educational action aimed at the prevention of skin cancer; and develop educational material for children and young individuals on this topic, encouraging the adoption of new habits for the prevention of skin cancer.

\section{Material and Methods}

This was a quasi-experimental, descriptive study, aimed at the application of an educational intervention on the prevention of skin cancer, whose results were qualitatively analyzed. The intervention was aimed at students in the eighth grade of primary school at a public school in the countryside of São Paulo and was mediated by a teacher specifically prepared to act as a facilitator. The teacher's preparation was conducted by the CSD researcher through two dialogical activities, of three hours each, in which the component elements of the educational intervention were worked out. Both this process and the application of the educational intervention took place at the school itself, during the students' class hours (Deponte et al., 2021).

The teacher, the students and their guardians signed the Free and Informed Consent Term (ICF) and/or the Free and Informed Consent Form (TALE) in accordance with Resolution 466/2012 of the National Health Council (Conselho Nacional de Saúde, 2018).

\subsection{Data Collection Instruments}

Two reports were used, answered by the teacher, to characterize the school environment regarding sun protection policy and another to characterize the teacher, named, respectively, R1 and R2.

The questionnaires answered by the students were: Q1 questionnaire, composed of closed questions of sociodemographic and phenotypic data related to risk factors for skin cancer and Q2 questionnaire, composed of open questions about influential factors in the practice of photoprotective attitudes.

\subsection{Participants}

A teacher participated in the dialogic meetings and concluded the educational program with 32 students from the eighth grade of a public primary school. The inclusion criteria for participating students was being able to read, write and understand in Portuguese, and the conclusion of the educational program taught by the teacher, previously trained by the researcher. Those whose guardians did 
not authorize data collection through the survey questionnaires and/or who did not participate in the activities proposed by the teacher were excluded from the study (Deponte et al., 2021).

\subsection{Activities to Prepare the Facilitating Teacher}

There were two activities totaling six hours of duration, carried out in fifteen days. On the occasions, the researcher and the teacher organized the themes and their respective triggers, by an active teaching-learning strategy, to include several subjects in the school curriculum and value triggers that mobilized greater interaction for the construction of meaningful on skin cancer and its prevention (Deponte et al., 2021).

\subsection{Educational Program}

This educational program used active teaching-learning methods and totaled 15 hours of activities distributed in 10 meetings of 90 minutes each. The activities were held weekly over 75 days (Reynolds et al., 1996; Bastuji-Garin et al., 1999; Simmons et al., 2017; Souza et al., 2018; Guy et al., 2016; Jha et al., 2017; Deponte et al., 2021).

The material produced for the conformation of the educational intervention considered the guidelines of the Ministry of Health (Ministério da Saúde do Brasil, 2018), of the Brazilian Society of Dermatology (Sociedade Brasileira de Dermatologia, 2018) and the Sol Amigo da Infância Program (Sociedade Brasileira de Dermatologia, 2017; Instituto Melanoma Brasil, 2013) as well as educational materials from the Australian and New Zealander program "SunSmartSchool" (Sun Smart School, 2019). Other elements from websites, such as the National Institute for Space Research and the Center for Weather Forecasting and Climate Studies (2019) and educational videos from Youtube ${ }^{\mathrm{TM}}$, were also incorporated.

The triggers and topics covered are summarized in the following Table 1.

Table 1. The ten triggering activities of the educational program.

\begin{tabular}{|c|c|c|c|}
\hline & Titles & Triggers & Activities \\
\hline 1 & I felt it on the skin & $\begin{array}{l}\text { Report of a patient undergoing treatment for } \\
\text { melanoma }\end{array}$ & $\begin{array}{l}\text { Dialogical discussion about personal or family } \\
\text { stories about the topic }\end{array}$ \\
\hline 2 & $\begin{array}{l}\text { I can't see it, but I can feel } \\
\text { it }\end{array}$ & $\begin{array}{l}\text { Experiment with tonic water and a UVR pen } \\
\text { that causes quinine to shine. }\end{array}$ & $\begin{array}{l}\text { Remember the composition of the sun's rays and } \\
\text { talk about the protective measures for animals }\end{array}$ \\
\hline 3 & Keeping an eye on the sun & $\begin{array}{l}\text { Visit the Climate Research Institute's } \\
\text { website }\end{array}$ & $\begin{array}{l}\text { Recognize weather conditions that interfere with } \\
\text { UVR intensity }\end{array}$ \\
\hline 4 & $\begin{array}{l}\text { Peoples History and } \\
\text { Photoprotection }\end{array}$ & $\begin{array}{l}\text { Experiment measuring water temperature in } \\
\text { different places in the school environment }\end{array}$ & $\begin{array}{l}\text { Discuss mechanical photoprotection and correlate } \\
\text { it with human attitudes }\end{array}$ \\
\hline 5 & $\begin{array}{l}\text { Tanning is not healthy at } \\
\text { all }\end{array}$ & Introduction to sunscreen & $\begin{array}{l}\text { Understand characteristics of topical } \\
\text { photoprotection and how to use it }\end{array}$ \\
\hline 6 & Everyone is at risk & $\begin{array}{l}\text { Classification of skin phototypes with public } \\
\text { persons as an example }\end{array}$ & Learn the different skin phototypes and self-assess \\
\hline
\end{tabular}




\begin{tabular}{|c|c|c|c|}
\hline 7 & $\begin{array}{l}\text { Keeping an eye on the } \\
\text { skin }\end{array}$ & MS and SBD primers & $\begin{array}{l}\text { Perform skin self-examination and train with } \\
\text { classmates }\end{array}$ \\
\hline 8 & Deadly Machine & Anvisa's legislation on Artificial Tanning & Talk about "tan culture" \\
\hline 9 & $\begin{array}{l}\text { Do not chicken out when } \\
\text { taking care of your skin }\end{array}$ & The school environment itself & $\begin{array}{l}\text { Reflect on how to promote protective measures in } \\
\text { the school environment }\end{array}$ \\
\hline 10 & Skin protectors & Habits of students and families & $\begin{array}{l}\text { Thinking about how to encourage society to adopt } \\
\text { healthy attitudes }\end{array}$ \\
\hline
\end{tabular}

Source: Deponte et al., 2021.

\subsection{Data Analysis}

Qualitative analysis followed the steps for Content Analysis in the Thematic Modality proposed by Bardin (2011): pre-analysis: initial reading of texts to identify meanings and ideas, in a fluent way; exploration of the material, with organization and categorization of the main ideas; and inferences and interpretation of the categorized ideas.

\section{Results and Discussion}

\subsection{Characterization of the School and the Teacher}

The educational institution is a public primary and secondary school. It has 731 students enrolled. The classes have, on average, 40 students and 9 teachers each. The teaching method used is traditional, disciplinary, although there are some movements to integrate contents. Short courses on active learning methods for teachers were reported.

The physical space has an extensive outdoor area for socializing and dining with proper physical and tree coverage to house students, in addition to covered and open multi-sport courts. Physical education classes are not restricted to the safest hours of sun exposure (before 10a.m. and after 4p.m.).

Regarding internal policies aimed at photoprotection of students and teachers, permission for the use of hats during breaks between classes was mentioned. There was no mention of the effectiveness of sun protection measures or guidance and incentives given by teachers to parents or students.

In the primary school curriculum, solar radiation and specifically UV and its consequences are addressed in the ninth grade and in the Science subject.

The facilitating teacher of the intervention has a bachelor's degree in Biology, and has been teaching Science for 8 years. The teacher reported having participated in the training of active teaching methods and having already used instruments based on these methods in educational activities.

The most prevalent sociodemographic characteristics of the students participating in the study were represented in Table 2 .

The phenotypic characteristics of students related to the risk for skin cancer are represented in the Figure 1 with the graphs below.

Low skin phototypes correspond to a minority of students, corresponding to 


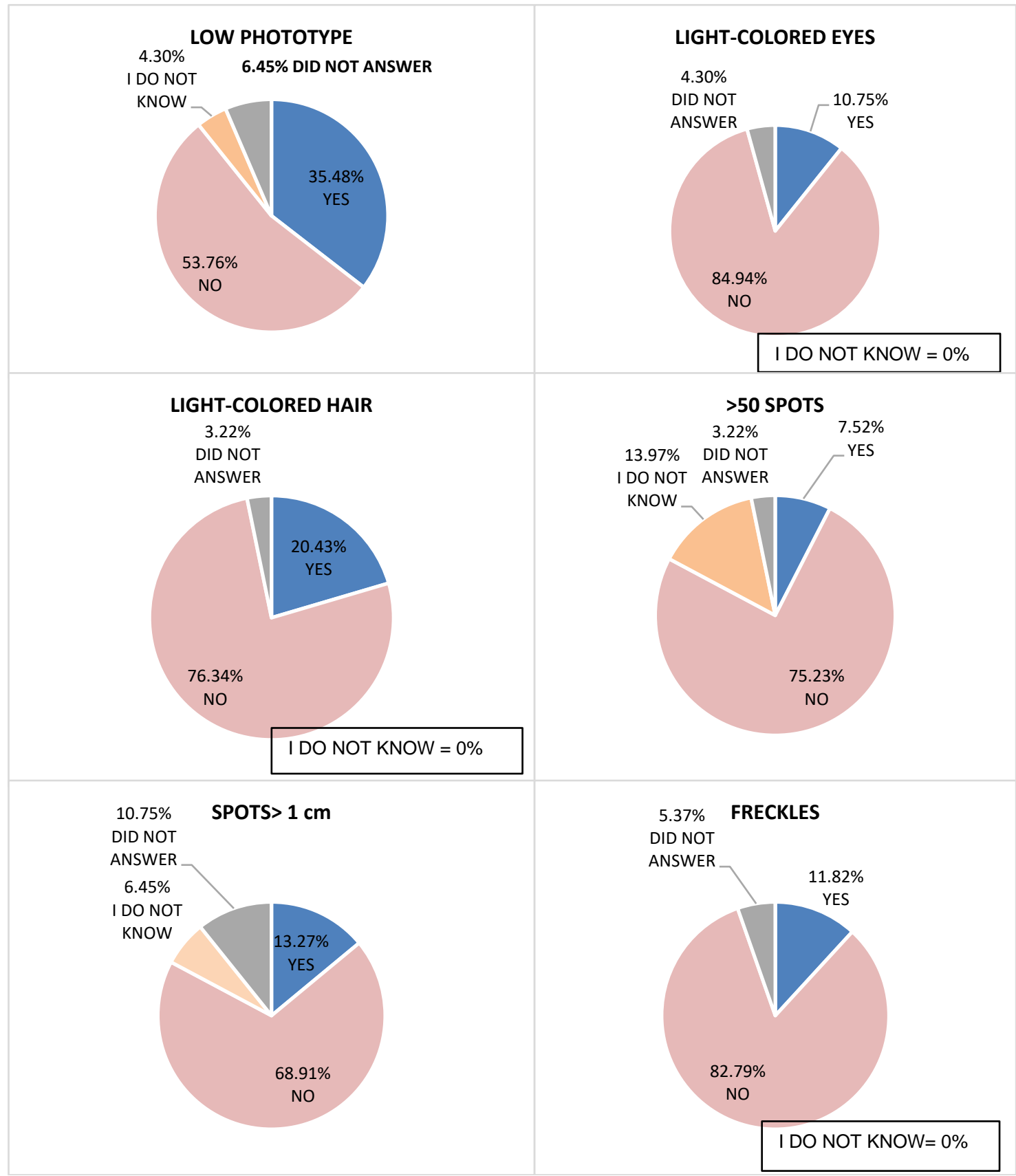

Figure 1. Phenotypic characteristics of risk for skin cancer in students.

$35.48 \%$; in a smaller percentage, there are still students with light-colored eyes and hair, in addition to freckles, not exceeding $20 \%$ of the total. Likewise, the number of spots and large spots are not prevalent factors in this student population, appearing in $7.52 \%$ and $13.27 \%$ of students, respectively.

It is evident that a considerable portion of students had difficulty in answering and demonstrates lack of knowledge about such important physical characteristics, denoting little attention to this body segment. The same is true for family history of skin cancer and other cancers, in which more than $20 \%$ of students were unable to answer, again representing little concern with the topic. 
Table 2. Sociodemographic characteristics of students according to their highest percentages.

\begin{tabular}{ccc}
\hline \multicolumn{2}{c}{ Characterization considering the highest percentages } \\
\hline Gender & Female & Male \\
& $47 \%$ & $53 \%$ \\
\hline Age & 14 years & 13 years \\
& $54 \%$ & $33 \%$ \\
\hline Skin color & White & Brown \\
& $49.5 \%$ & $44 \%$ \\
\hline Parents' Education & Secondary school & Higher education \\
& $38.5 \%$ & $24.1 \%$ \\
\hline Monthly family income & $1-3$ Minimum wages & $3-5$ and more than 5 \\
& $44 \%$ & $19 \%+15.4 \%$ \\
\hline
\end{tabular}

Although physically the minority of students is at high risk for skin cancer, we have the opposite in terms of behavior. More than $60 \%$ of students report frequent sun exposures and episodes of sunburn, presenting high vulnerability.

\subsection{Qualitative Study on Q2}

The answers given to two open questions from the Q2 questionnaire were analyzed:

1) "Talk about the ease of carrying out the actions we must do every day to reduce the risk of skin cancer."

2) "Talk about the difficulties of carrying out the actions we must do every day to reduce the risk of skin cancer."

Cursive answers were grouped into two broad categories:

1) access to strategies;

2) construction of habits.

The "access to strategies" category encompasses the following subcategories: products, knowledge and care, which constitute the items for adequate photoprotection and its general meaning brings the idea of the ability to possess, enjoy or acquire the needs of photoprotection and daily care in the prevention of skin cancer; the "construction of habits" category, which includes the subcategories adherence, organization and weather, whose general meaning expresses limitations and ease of carrying out the necessary attitudes for daily care in the prevention of skin cancer, and are shown in Table 3.

Analyzing the cursive answers, it was identified that some students considered the skin cancer prevention measures simple and quick, which was categorized as "access to strategies" and subcategorized as "care". However, the superficial approach of the students was evident, inattentive to the proper adoption of the measure to ensure its effectiveness, as mentioned by Oliveira et al. (2019), among students of a surf school, with reference to the use of sunscreen, mentioned generically, as verified in the following answers: 
Table 3. Grouping into categories and subcategories regarding the meanings of the answers to the Q2 questionnaire.

\begin{tabular}{|c|c|c|}
\hline Categories & Subcategories & Senses \\
\hline \multirow{3}{*}{ "Access to strategies" } & Product & $\begin{array}{l}\text { Students have sunscreen, sunglasses, hat and caps at home. } \\
\text { Students do not have the financial means to buy sunscreen. } \\
\text { Students do not wear sunglasses because they wear prescription glasses. }\end{array}$ \\
\hline & Care & $\begin{array}{l}\text { The ease of performing daily care: putting on sunscreen, wearing a cap, going } \\
\text { to the doctor. } \\
\text { Difficulty in providing care due to laziness or lack of time. }\end{array}$ \\
\hline & Knowledge & $\begin{array}{l}\text { Everyone has enough knowledge to perform photoprotection. } \\
\text { These are simple actions. } \\
\text { Students do not do the actions because they believe acne or allergy would get } \\
\text { worse, or because they have to produce vitamin D, or because family members } \\
\text { say it is good to be exposed to the sun. } \\
\text { Some people lack knowledge of how to prevent skin cancer. }\end{array}$ \\
\hline \multirow{3}{*}{ "Construction of habits"- } & Adhesion/appreciation & $\begin{array}{l}\text { Students forget about the risk of developing skin cancer. } \\
\text { Students do not think it is important. } \\
\text { Students forget to do the action. } \\
\text { Students do not like to wear sunscreen, or long-sleeved shirts and pants. }\end{array}$ \\
\hline & Organization & $\begin{array}{l}\text { The day-to-day rush and lack of time prevent the performance of actions. } \\
\text { Having to apply sunscreen or waking up earlier for this purpose. }\end{array}$ \\
\hline & Weather/climate & $\begin{array}{l}\text { Does not use physical measures such as clothing because of the heat, or only } \\
\text { uses it on cold days. }\end{array}$ \\
\hline
\end{tabular}

"Just wear sunscreen, you just have to apply it" (E01),

"Applying sunscreen every day is something that doesn't take long" (E04),

"Very easy, just take care of yourself" (EO2)

Despite this apparent naturalness mentioned by some, most students consider photoprotective measures a difficult task to be performed, which generated the category "construction of habits". Whatever hinders the adoption of photoprotection was subcategorized into "adherence/appreciation" with statements that reflected a certain omnipotence of the adolescent in face of the risks of skin cancer and neglect of health care, and contempt regarding the damage that the sun causes to the skin (Fitch-Martin et al., 2018):

"Being lazy to apply sunscreen" (E17),

"Wake up early to apply sunscreen" (E20),

"Rushing and lack of time, thinking it is not important" (E12).

As well as speeches that referred to the subcategory "organization" focused on the use of time in everyday life:

"Sometimes I just don't have time" (E15),

Sunscreen is then cited many times as not the only but the most important measure of photoprotection. Such information is not similar to qualitative research carried out with workers exposed to the sun, which cite physical protection as the main measure, through appropriate clothing as the main measure. This is because this research was carried out in cold climate countries, probably 
highlighting a lack of qualitative research on this topic in our country and continent (Zink et al., 2017; Jopson \& Reeder, 2006; Rodriguez et al., 2017).

The economic issue was also often cited as a difficulty in complying with photoprotective measures, whether for the acquisition of sunscreen or other measures, and were gathered in the category "access to strategies", in the subcategory "products", as mentioned below:

"There are people who are allergic to sunscreen and they have to find a correct one, but it is more expensive." (E10)

"People cannot afford good sunscreen" (E14),

"Sometimes sunscreen is very expensive and some families cannot buy it" ( $E$ 25)

It was also interesting to observe different statements citing the use of eyeglasses as an impediment to the use of sunglasses. From these statements we can infer that students are unaware of the possibility of adding prescription to solar lenses or that the economic factor would limit their acquisition. The category "access to strategies" was grouped as subcategory "knowledge":

"I don't wear sunglasses because I wear eye glasses." (E23)

Other difficulties that reflect misinformation were also identified in the same "knowledge" subcategory:

"My doctor said I need vitamin D." (E25)

"But with acne breakouts, $P \mathrm{~m}$ afraid to apply sunscreen and get worse." (E03)

"My parents say it s good to sunbathe once in a while." (E19)

"There is a lack of knowledge, information on prevention and

some people may not care about the risks the sun can cause us." (E02)

The need for vitamin D production and, therefore, for sun exposure, is a belief that also appears in other studies (Carley \& Stratman, 2015; Mazloomy Mahmoodabad et al., 2019).

Finally, in the subcategory "weather/climate" identified in the students' answers as hindering factors in "construction of habits" for the prevention of skin cancer:

"I wear a long-sleeved shirt in the cold" (E09),

"They don't always wear a long-sleeved shirt because it's hot" (E02),

"I don't like shirts or pants" (E09),

“Because I don't like it" (E05)

The high temperatures prevalent in all months of the year appear as an important factor that prevents the adoption of mechanical measures such as the use of long-sleeved shirts, pants and hats. There is a preference for shorter clothing, also due to the tropical climate and style of this age group of the population.

In summary, we did not observe the interference of religion or spirituality as a factor that negatively influences the performance of actions. We also did not see fear or worry of having skin cancer in the students' answers, because they did not have bad experiences related to skin cancer, as mentioned by some international qualitative research (Carley \& Stratman, 2015; Mazloomy Mahmoodabad et al., 2019). The perception of risk for skin cancer is underestimated, as also 
mentioned in the literature (Zink et al., 2017; Jopson \& Reeder, 2006; Rodriguez et al., 2017).

Students treat photoprotection measures with superficiality, without rigor and importance, demonstrate negligence and invulnerability against the risk of skin cancer. They demonstrate ignorance regarding other issues such as the use of sunglasses, influence on acne and the production of vitamin $\mathrm{D}$. They also mention the difficulty with long clothes due to the heat, and the financial difficulty in acquiring sunscreen.

The analysis shows the need for a unique educational program for childhood and adolescence, involving family members and educators, focusing on all measures other than sunscreen, and that demonstrate the damage the sun causes to the skin, effectively sensitizing them from everyday situations. The participation of the educational system, the media and health professionals is essential for raising awareness in society, promoting its responsibility, abandoning ingrained harmful attitudes and practicing new conscious habits of photoprotection (Jopson \& Reeder, 2006; Rodriguez et al., 2017).

The encouragement of these practices by educational institutions also appears as a deficit. A sequential, spiraling approach to the subject is needed, with greater frequency in the curriculum in Early Childhood, Primary and Secondary School (Deponte et al., 2021). It is important that schools adopt photoprotection policies in the physical school environment and that teachers encourage positive photoprotection attitudes (Deponte et al., 2021).

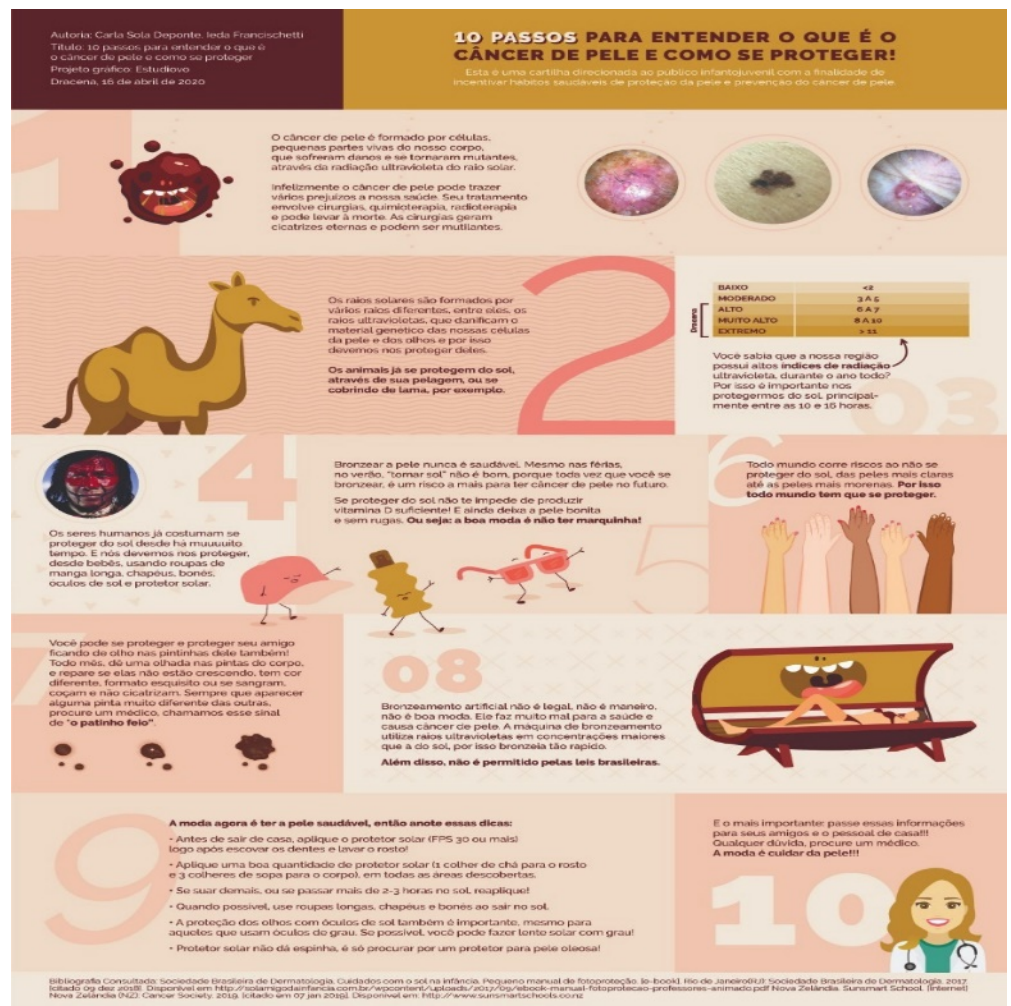

Figure 2. Educational material on photoprotection and prevention of skin cancer, aimed at children and adolescents. 
Based on the results presented, educational material was created, which synthesizes the educational action, using language aimed at children and adolescents, named " 10 steps to understand what skin cancer is and how to protect yourself", represented in the Figure 2.

\section{Conclusion}

The research brings us relevant information that can be added to the educational program, addressing changes common to adolescence and health, such as acne, refractive errors in vision and vitamin $\mathrm{D}$, which should be better clarified so that they are no longer cited as factors preventing photoprotection.

When working with adolescents, it is clear that it is important that the questionnaires are more succinct and that the benefits of participation are offered for greater adherence and commitment (Alonso et al., 2020; Deponte et al., 2021).

There is still little knowledge about the difficult reality of the treatment and prognosis of some skin cancers, electing this topic as very little discussed and disseminated and, therefore, an intervention that emphasizes these aspects would cause greater impact and perception of the risk of skin cancer by students (Deponte et al., 2021).

There is a need for a differentiated approach to a young audience, including biological and psychological changes inherent to adolescence, seeking to promote knowledge, awareness and healthy attitudes (Reynolds et al., 1996; Bastuji-Garin et al., 1999; Simmons et al., 2017; Deponte et al., 2021).

Measures addressed in the educational program following the precepts of active learning methods (Thomson, 2006; Lima, 2017; Deponte et al., 2021) enable greater involvement and integration of students with the topic, making them aware of new actions and healthy practices to prevent skin cancer.

The way to shape attitudes and develop habits for the prevention of skin cancer seems to be through active teaching-learning methodologies, using sequential, continuous, repetitive, training and problem solving approaches, joining the efforts of family members and the city's educational and health institutions (Lin et al., 2011; Alonso et al., 2020; Reynolds et al., 1996; Deponte et al., 2021).

\section{Approval}

Considering the ethical aspects of research involving human beings, the project was submitted for approval by the Research Ethics Committee of the School of Medicine of Marília-FAMEMA, opinion number 3.213.679 of March 21, 2019 and had the authorization of the Municipal Department of Education of the participating school's municipality. This study is in accordance with the standards and regulatory guidelines for research involving human beings and the premises of Resolution 466/2012 of the National Health Council.

\section{Acknowledgements}

Thanks to Dr. Haroldo Deponte, an inspiration in Patient Care and Health Educa- 
tion.

\section{Conflicts of Interest}

The authors declare no conflicts of interest regarding the publication of this paper.

\section{References}

Alonso, F., Gonzalez-Marin, A., Esteban, C., \& Useche, S. A. (2020). Behavioral Health at School: Do Three Competences in Road Safety Education Impact the Protective Road Behaviors of Spanish Children? International Journal of Environmental Research and Public Health, 17, 935. https://doi.org/10.3390/ijerph17030935

Bardin, L. (2011). Análise de conteúdo (p. 229). Edições 70.

Bastuji-Garin, S., Grob, J. J., Grognard, C., \& Grosjean, F. (1999). Melanoma Prevention: Evaluation of a Health Education Campaign for Primary Schools. Archives of Dermatology, 135, 936-940. https://doi.org/10.1001/archderm.135.8.936

Bataille, V. (2013). Sun Exposure, Sunbeds and Sunscreens and Melanoma. What Are the Controversies? Current Oncology Reports, 15, 526-532.

https://doi.org/10.1007/s11912-013-0342-4

Brasil, Ministerio da Saude, Secretaria de Atençao a Saude, Instituto Nacional de Cancer (2010). Coordenaçao Geral de AçoesEstrategicas. Coordenaçao de Prevençao e Vigilancia. Estimativa 2010: Incidencia de Cancer no Brasil. Rio de Janeiro.

Brasil. Centro de Previsão do Tempo e Estudos Climáticos. (National Institute for Space Research and The Center for Weather Forecasting and Climate Studies) [Internet] Instituto Nacional de Pesquisas Espaciais. 2019. http://tempo.cptec.inpe.br

Brasil. Instituto Melanoma Brasil. Foz do Iguaçu (PR): Instituto Melanoma Brasil; c 2013. http://www.melanomabrasil.org/nossa-historia

Brasil. Youtube. https://www.youtube.com

Buller, D. B., Cokkinides, V., Hall, H. I., Hartman, A. M., Saraiya, M., Miller, E. et al. (2011). Prevalence of Sunburn, Sun Protection, and Indoor Tanning Behaviors among Americans: Review from National Surveys and Case Studies of 3 States. Journal of the American Academy of Dermatology, 65, S114-S123. https://doi.org/10.1016/j.jaad.2011.05.033

Carley, A., \& Stratman, E. (2015). Skin Cancer Beliefs, Knowledge, and Prevention Practices: A Comparison of Farmers and Nonfarmers in a Midwestern Population. Journal of Agromedicine, 20, 85-94. https://doi.org/10.1080/1059924X.2015.1010059

Chen, A. C., Halliday, G. M., \& Damian, D. L. (2013). Non-Melanoma Skin Cancer: Carcinogenesis and Chemoprevention. Pathology, 45, 331-341. https://doi.org/10.1097/PAT.0b013e32835f515c

Chinem, V. P., \& Miot, H. A. (2011). Epidemiology of Basal Cell Carcinoma. Anais Brasileiros de Dermatologia, 86, 292-305. https://doi.org/10.1590/S0365-05962011000200013

Conselho Nacional de Saúde (Brasil). Resolução No. 466, de 12 de dezembro de 2012. Brasília, 2012. Disponível em.

http://www.conselho.saude.gov.br/web comissoes/conep/index.html

Da Rocha, C. R. M., Tronco, A., Borba, F. W., \& Lunelli, J. (2018). Fotoexposição: Hábitos e conhecimentos de estudantes de Medicina. Revista Brasileira de Medicina da Saúde, 2, 149-154. https://doi.org/10.4034/RBCS.2018.22.02.08 
Deponte, C., Antigo, E., Rossetto, I., Mansano, M., Deponte, S., \& Francischetti, I. (2021). Educational Action in Adolescents of a Public School about the Prevention of Skin Cancer. Creative Education, 12, 584-598. https://doi.org/10.4236/ce.2021.123040 http://www.scirp.org/journal/paperinformation.aspx?paperid=107806

Eppinger, B., Walter, M., Heekeren, H. R., \& Li, S. C. (2013). Of Goals and Habits: Age-Related and Individual Differences in Goal-Directed Decision-Making. Frontiers in Neuroscience, 7, 253.

Fitch-Martin, A. R., Menger, L. M., Loomis, A. D., Hartsough, L. E. S., \& Henry, K. L. (2018). "We Don't Really Do Anything Unless It's Really Bad": Understanding Adolescent Sun Protective Knowledge, Attitudes and Behaviors in the U.S. The Journal of Primary Prevention, 39, 371-386. https://doi.org/10.1007/s10935-018-0515-x

Fitzpatrick, T. B. (1988). The Validity and Practicality of Sun-Reactive Skin Types I through. Archives of Dermatology, 124, 869-871.

https://doi.org/10.1001/archderm.1988.01670060015008

Guy, G. P., Holman, D. M., \& Watson, M. (2016). The Important Role of Schools in the Prevention of Skin Cancer. JAMA Dermatology, 152, 1083.

https://doi.org/10.1001/jamadermatol.2016.3453

INCA (2009). Tendências Regionais da Mortalidade por Câncer no Estado de Sao Paulo 2000 a 2010/Mendes JDV e Cecilio MAPM. BEPA 2012, 9, 24-45.

Jha, D., Jha, S., Ghosh, S., Smylie, M., \& Taher, M. J. (2017). Sun-Smart Practices amongst School Students (Grades 5, 7, and 9) in Alberta, Canada. Journal of Cutaneous Medicine and Surgery, 21, 137-144. https://doi.org/10.1177/1203475417692574

Jopson, J. A., \& Reeder, A. I. (2006). Are NZ Primary School SunSmart? Social and Behavioural Research in Cancer Group, Department of Preventive and Social Medicine. http://www.sunsmartschools.co.nz/FinalSunSmartSchoolBaseline-append.pdf

Lima, V. V. (2017). Espiral construtivista: Uma metodologia ativa de ensino-aprendizagem. Interface (Botucatu), 21, 421-434. https://doi.org/10.1590/1807-57622016.0316

Lin, J. S., Eder, M., \& Weinmann, S. (2011). Behavioral Counseling to Prevent Skin Cancer: A Systematic Review for the U.S. Preventive Services Task Force. Annals of Internal Medicine, 154, 190-201. https://doi.org/10.7326/0003-4819-154-3-201102010-00009

Lomas, A., Leonardi-Bee, J., \& Bath-Hextall, F. (2012). A Systematic Review of Worldwide Incidence of Nonmelanoma Skin Cancer. British Journal of Dermatology, 166, 1069-1080. https://doi.org/10.1111/j.1365-2133.2012.10830.x

Lower, T., Girgis, A., \& Sanson-Fisher, R. (1998). The Prevalence and Predictors of Solar Protection Use among Adolescents. Preventive Medicine, 27, 391-399.

https://doi.org/10.1006/pmed.1998.0309

Martinez, M. A. R., Francisco, G., Cabral, L. S., Ruiz, I. R. G., \& Neto, C. F. (2006). Genética molecular aplicada ao câncer cutâneo não melanoma. Anais Brasileiros de Dermatologia, 81, 405-419. https://doi.org/10.1590/S0365-05962006000500003

Mazloomy Mahmoodabad, S. S., Sotoudeh, A., Vaezi, A. A., Fallahzadeh, H., \& Noorbala, M. T. (2019). Evaluating Perceived Threat of Skin Cancer and Preventive Measures in South Iranian Sailors: A Qualitative Study. Journal of Education and Health Promotion, 31, 262.

Nilsen, L. T., Hannevik, M., \& Veierød, M. B. (2016). Ultraviolet Exposure from Indoor Tanning Devices: A Systematic Review. British Journal of Dermatology, 174, 730-740. https://doi.org/10.1111/bjd.14388

Oliveira, M., Aragão, K., Reis, N., Silva, L., Costa, M., Sousa, L., Araújo, M., \& Nascimento, F. (2019). Prevenção à exposição solar: Percepção dos alunos de uma escola de surf. 
Revista Pesquisa Qualitativa, 7, 295-311.

https://doi.org/10.33361/RPQ.2019.v.7.n.14.260

Pan American Health Organization (2018). https://www.paho.org/pt/topicos/cancer

Reynolds, K. D., Blaum, J. M., Jester, P. M., Weiss, H., Soong, S. J., \& Diclemente, R. J. (1996). Predictors of Sun Exposure in Adolescents in a Southeastern U.S. Population. Journal of Adolescent Health, 19, 409-415. https://doi.org/10.1016/S1054-139X(96)00050-X

Ribeiro, S., Glass, D., \& Bataille, V. (2016). Genetic Epidemiology of Melanoma. European Journal of Dermatology, 26, 335-339. https://doi.org/10.1684/ejd.2016.2787

Rodriguez, V. M., Shuk, E., Arniella, G., González, C. J., Gany, F., Hamilton, J. G. et al. (2017). A Qualitative Exploration of Latinos' Perceptions about Skin Cancer: The Role of Gender and Linguistic Acculturation. Journal of Cancer Education, 32, 438-446. https://doi.org/10.1007/s13187-015-0963-4

Rodriguez-Zamorano, P., Puebla-Tornero, L., Martín-Santos, L. M., Román-Villaizán, M. L., \& Guerra-Tapia, A. (2018). Estudio transversal sobre larepercusion de lainformacion educativa enlos hábitos de fotoproteccion tópica enestudiantes de medicina. $\mathrm{Me}$ dicina de Familia. SEMERGEN, 44, 420-429.

https://doi.org/10.1016/j.semerg.2018.02.004

Sampaio, S. A. P., \& Rivitti, E. A. (2018). Dermatologia (4th ed.). Artes Médicas, American Cancer Society.

Schalka, S. et al. (2014). Brazilian Consensus on Photoprotection. Anais Brasileiros de Dermatologia, 89, 1-74. https://doi.org/10.1590/abd1806-4841.20143971

Simmons, R. A., Cosgrove, S. C., Romney, M. C., Plumb, J. D., Brawer, R. O., Gonzalez, E. T., \& Moore, B. S. (2017). Health Literacy: Cancer Prevention Strategies for Early Adults. American Journal of Preventive Medicine, 53, S73-S77. https://doi.org/10.1016/j.amepre.2017.03.016

Sociedade Brasileira de Dermatologia (2017). Calculadora do Risco de câncer de pele. SBD. http://www.sbd.org.br/dezembroLaranja/calculadora

Sociedade Brasileira de Dermatologia (2018). Cuidados com o sol na infância. Pequeno manual de fotoproteção. Sociedade Brasileira de Dermatologia.

https://www.researchgate.net/publication/273768969 Sol amigo da infancia semean do uma nova cultura em fotoprotecao Sun friend of childhood

Souza, E. F., Silva, A. G., \& Silva, A. I. (2018). Active Methodologies for Graduation in Nursing: Focus on the Health Care of Older Adults. Revista Brasileira de Enfermagem, 71, 920-924. https://doi.org/10.1590/0034-7167-2017-0150

Szklo, A. S., Almeida, L. M., Figueiredo, V., Lozana, J. A., Mendonça, G. A. S., Moura, L. et al. (2007). Comportamento relativo à exposição e proteção solar na população de 15 anos ou mais de 15 capitais brasileiras e Distrito Federal, 2002-2003. Cadernos de Saúde Pública, 23, 823-834. https://doi.org/10.1590/S0102-311X2007000400010

Thomson, J. A. (2006). Issues in Safety Education Interventions. Injury Prevention, 12, 138-139. https://doi.org/10.1136/ip.2006.012625

Weyers, W. (2012). The "Epidemic" of Melanoma between Under- and Over-Diagnosis. Journal of Cutaneous Pathology, 39, 9-16.

https://doi.org/10.1111/j.1600-0560.2011.01831.x

Zink, A., Wurstbauer, D., Rotter, M., Wildner, M., \& Biedermann, T. (2017). Do Outdoor Workers Know Their Risk of NMSC. Perceptions, Beliefs and Preventive Behaviour among Farmers, Roofers and Gardeners? The Journal of the European Academy of Dermatology and Venereology, 31, 1649-1654. https://doi.org/10.1111/jdv.14281 